\title{
From Science to Popularization, and Back - The Science and Journalism of the Belgian Economist Gustave de Molinari
}

\author{
Maarten Van Dijck
}

KADOC, Catholic University Leuven, Belgium

\section{Argument}

Sociologists and historians of science, such as Richard Whitley and Stephen Hilgartner, identified a culturally dominant discourse of science popularization in the broader society. In this dominant view, a clear distinction is maintained between scientific knowledge and popularized knowledge. Popularization of science is seen as the process of transmitting real science to a lay public. This discourse on science popularization was criticized by Whitley and Hilgartner as an inadequate simplification. Yet, the battered traditional model of popularization remains remarkably resistant to these theoretical attacks. In this paper I will argue, based on research of the output of the Belgian economist Gustave de Molinari (1819-1912), and more specifically, his opinion on the role of government in economic life, that the boundary between science and popularization in political economy is not clear and that the status of scientists fluctuates over time and in different contexts. It is therefore impossible for historians or economists to distinguish science from popularization based on the essential characteristics or intrinsic quality of the work. De Molinari's ideas are followed through the different media of science and journalism. Although de Molinari himself differentiated between his scientific and "popular" work, the boundary between science and popularization proves to be highly permeable, in both directions.

\section{Traditional and New Views of Popularization}

Richard Whitley first identified a tacit consensus in the existing scientific literature and in the broader society about the definition of popularization. In this view, popularization was considered "the transmission of scientific knowledge from scientists to the lay public for purposes of edification, legitimation and training" (Whitley 1985, 3). Popularization is viewed as being separate from knowledge production and consequently as a two-step process. First, knowledge is produced and validated in an esoteric process. This implies that there are clear boundaries between the scientist and the lay public. Next, this knowledge is disseminated to a wider public. In this second step, knowledge is recast into everyday language for non-specialists who cannot easily understand specialist ideas. This process includes appropriate simplification and 
even inadequate distortion (Hilgartner 1990, 519). Feedback from popularization into science is inconsistent with this traditional view. Popularization is not regarded as part of the research process, but is typically seen as a low-status activity. ${ }^{1}$ Recently the traditional view has been upheld by Jutta Schickore using the example of the eminent German physician and physiologist Hermann von Helmholtz (1821-1894). Helmholtz's writings correspond very well to the traditional two-step model of science popularization and he himself thought of his work in these terms (Schickore 2001, 414).

The traditional or dominant view of science popularization has been attacked as inadequate by several scholars in the history and sociology of science. Stephen Hilgartner argues that it does not take into account the ambiguity of the concepts of genuine science and popularization. The dominant view rests upon the assumption that the boundary between genuine and popularized knowledge is unproblematic. If scientific knowledge is produced by experts and presented to scientific audiences, it leaves us with the question of how to identify those experts. Michel Cloitre and Terry Shinn have suggested a new interpretation of the relationship between science and popularization as "a continuum where categories of texts are not completely separated from one another." They propose an expository typology that ranges from specialist texts to popular articles with different configurations of argument, image, and referent (Cloître and Shinn 1985, 58). Jane Gregory has addressed the issue of popularization using as a case study the accounts of Fred Hoyle's life-from-space theory in different media over time. This respected astrophysicist developed his theory in popular books before starting to communicate it in academic papers. Hoyle was gradually marginalized by the astronomical establishment because of his theory. As a last resort to reach other scientists, he again turned to popular media. Gregory points to complex interactions among all media and opposes the view that popularization is peripheral to scientific activity (Gregory 2003, 25-27).

In this paper I will confront the different views of popularization through a case study of the Belgian political economist Gustave de Molinari. This will be done by comparing de Molinari's opinion on the role of government in the economy in his first theoretical works, De la Production de la Sécurité and Les Soirées de la Rue SaintLazare (both published in 1849), and his subsequent popularizing work in the journal L'Économiste Belge (1855-1868). Previous research on de Molinari has not considered his popularizing works of journalism, but kept strictly to his scientific contributions. Next I will move on to his textbook Cours d'Économie Politique (part II, 1863). ${ }^{2}$ Based

\footnotetext{
${ }^{1}$ Recently David Knight argued that popularization became a low status activity only after 1920. Before that, scientists could even boost their reputation by speaking before large lay audiences (Knight 2006, 5, 182-183).

${ }^{2}$ When analyzing the relationship between De la Production, Les Soirées, L'Économiste Belge, and the Cours, in the first part of the paper, I accept de Molinari's own stated intention to characterize his texts as either specialist or popularization. He stated in De la Production (1849a, 277) that he would study the function of government within the system of economic science. In the first issue of L'Économiste Belge (De Molinari 1855b, 3) de Molinari
} 
on this case, the two-step model proves inadequate to explain the relationship between science and popularization in the realm of political economy. The idea that science itself remains insulated from its popularized dissemination does not correspond to the evidence. Although de Molinari did make a distinction between his scientific writings and writings directed to a wider audience, it is clear that his popularization affected his knowledge production. As this paper documents, in his scientific work he returned to ideas he had developed in his popular work. The process of knowledge production was thus not insulated from science popularization.

After examining the relationship between science and popularization within de Molinari's work, I will adopt an externalist view. In this next research step I will investigate the line between who is considered a scientist and who is seen as a popularizer, exploring the reactions to de Molinari's work. Should de Molinari be considered a popularizer of the ideas that originated with Adam Smith? Or can he be regarded as a scientist? I will show how de Molinari slipped from one category to the other during his life, making it clear that differentiating between the experts and the lay public is not as easy as is suggested by the two-step popularization model. Before analyzing the relationship between the different texts and the scientific position of de Molinari, I will give a short introduction to his life and works.

\section{Gustave de Molinari and the Popularization of Economics in Mid-Nineteenth-Century France and Belgium ${ }^{3}$}

De Molinari was a Belgian economist, characterized by Murray N. Rothbard as "an unflinching champion of freedom and natural law" (Rothbard 1995, 453). He went to Paris in 1840 and became active in the circles of the French classical economists. He first published on the effect railways had on industrialization in 1843. In the middle of the 1840s, de Molinari became involved in the free trade movement in Paris. He wrote articles for different journals, the most important being the Journal des Économistes. ${ }^{4} \mathrm{He}$ was a member of the Société d'Économie Politique and Frédéric Bastiat's Association

indicated that it was the journal's mission to popularize the principles of political economy concerning the role of the government in the economy. In the Cours (1863, I, viii) he said he was engaged in purely scientific speculations. De Molinari's intention with Les Soirées is less clear: he did not indicate his audience. If Les Soirées were intended as popularization, then it seems that de Molinari was developing his ideas in 1849 simultaneously in his scientific and his popular publications, adding an additional argument against the two-step model.

${ }^{3}$ Unfortunately, no personal archive of Gustave de Molinari exists. This section is therefore to a large extent based on published materials. Most biographical details on de Molinari's life are found in Yves Guyot's obituary in the Journal des Économistes. Aged ninety-two, he passed away in Adinkerque in the presence of his daughterin-law Marie Le Roy who had served him as secretary (Guyout 1912, 183). His books were sold between 17 and 21 November 1913 (Catalogue des livres anciens 1913).

${ }^{4}$ Before 1852 two editions of the Journal des Économistes co-existed: a Paris-based version published by Guillaumin and a Brussels-based version by Méline, Cans et Cie, with a different numbering of volumes and pages. Throughout this paper I consistently used the Paris-based edition. 
Pour la Liberté des Échanges (Coquelin and Guillaumin 1852, II, 197). Stimulated by the success of the Anti-Corn Law League, he and his French colleagues hoped to convince public opinion and government of the ideas of the French classical economists working in the tradition of Adam Smith and Jean-Baptiste Say (Hart 1981a, 273-275).

Following the coup d'état by Napoleon III in 1851, de Molinari returned to Belgium. Thanks to the Belgian economist, politician, and mayor of Brussels, Charles de Brouckère, de Molinari was appointed professor of political economy at the Musée Royal de l'Industrie in Brussels. ${ }^{5}$ He also was appointed professor of economic geography and history at the public Institut Supérieur du Commerce in Antwerp (Heuschling 1860, 265-267). As of 1855 de Molinari became involved in the Belgian movement for policy reform. As in most of Europe, Belgian economists were trying to get their ideas center stage in policy discussions (Howe 1997, 73-86). Belgian economists started agitating for free trade after the repeal of the Corn Laws in 1846 in Great-Britain. Charles de Brouckère said during one of the first meetings of the Belgian Free Trade Association that it was the task of the economists to pervade society with scientific truth. He wanted the government to understand how and why the economy progressed so that they would make laws in accordance with the principles of political economy (Association Belge 1846, 12). The high point of the activities was the organization of the Congrès des Économistes in Brussels in September 1847 (Corr-Vandermaeren and Couvreur 1874).

In 1855 the Société Belge d'Économie Politique was established. It was inspired by the French political economy society and the London club. The idea was to discuss theory within a circle of economists. Moreover, the society would function as a means of popularizing economic science among a larger public. In the same year, the economists founded the Association Pour la Réforme Douanière which advocated the lowering of import duties (Erreygers 2001). Some politicians who had contacts with the Société Belge advocated free trade and laissez-faire in Parliament during the 1850s and 1860s (Van Dijck forthcoming 2008; Erreygers and Mosselmans 2005). De Molinari played a prominent role in several associations. Furthermore, he was the driving force behind the journal L'Économiste Belge. It became the most important mouthpiece for Belgian economists working in the liberal classical tradition (Suetens 1955, 63-65). De Molinari's best-known contribution to economic science was his 1849 essay De la Production de la Sécurité. He argued that if free competition led to more efficient production of goods and services, then the production of security should be left to the market too. De Molinari further elaborated on the subject in Les Soirées de la Rue Saint-Lazare. Entretiens sur les Lois Économiques et Défense de la Propriété (1849). He set out his complete thinking in his textbook Cours d'Économie Politique, based on his lectures at the Musée Royal (Hart 1981a, 276). The first part of the Cours

\footnotetext{
${ }^{5}$ The French economist Joseph Garnier introduced de Molinari to Charles de Brouckère (Garnier 1851).
} 
was published in 1855. The second volume, which included his thinking on the state, amongst other subjects, only appeared in $1863 .^{6}$

De Molinari returned to Paris in 1867. By this time the free trade movement in Belgium had lost momentum, firstly because some of its driving forces had either passed away or emigrated. The sponsors from the Verviers woollen district died in 1867 and 1869, and financial support subsequently dried up (Garnier 1869). Secondly, a large part of the free trade program had by then been implemented. Trade restrictions had been practically abandoned by the Belgian government. Nevertheless, de Molinari was not pleased with these results. In the last issue of L'Économiste Belge, he lamented that his program for a cheap state had not been achieved in Belgium (De Molinari 1868). In Paris, de Molinari started working as an editor for the Journal des Débats, which was closely linked to Léon Say, the grandson of Jean-Baptiste Say. In 1881, he became the director of the highly respected Journal des Économistes, a position he occupied until 1909 (Lubelski-Bernard 2001, 137).

David Hart, the author of an extensive series of articles on de Molinari (Hart 1981a, 1981b, and 1982), considered de Molinari to be the "most consistent of the French free trade liberal school" (Hart 1981a, 273). Rothbard appropriated de Molinari as the first anarcho-capitalist or free-market proprietary anarchist. However, de Molinari never considered himself an anarchist. On the contrary, he insisted that, left to its own devices, the economy was not anarchic, but indeed contained within itself a regulative principle (De Molinari 1855f, 6). I believe anti-authoritarian liberal or maybe even utopianliberal would be more suitable descriptions. In the next sections I will discuss the evolution of his ideas on the role of the state in De la Production de la Sécurité, Les Soirées de la Rue Saint-Lazare, L'Économiste Belge, and the second part of his Cours. In these different media, de Molinari's opinions about the role of the state varied considerably.

\section{The French Tradition of Political Economy and de Molinari's De la Production de la Sécurité}

The British classical economists were not very consistent defenders of laissez-faire, as shown by Jacob Viner (1927), Lionel Robbins (1952), and Denis Patrick O’Brien

\footnotetext{
${ }^{6}$ Some confusion exists over the date of publication of the second part of the Cours. In 1855, only the first part, on the production and distribution of wealth, was published. This part went into a second revised edition in 1863. The second part of the Cours, on the circulation and consumption of wealth, only appeared in 1863, at the same time as the second revised edition of the first part. The second part was therefore mistakenly seen as a second edition. The fact that de Molinari's Brussels-based publisher, Lacroix-Verboeckhoven, presented it on the cover as a second edition lies at the bottom of this confusion. De Molinari's introduction confirms that the second part of the Cours was only written at the beginning of the 1860s. He excuses himself to the buyers of the first part for only publishing the promised second part in 1863 (De Molinari 1863, I, viii). Moreover, he changed his original plan completely: in 1855, he had announced that he would publish four more parts: on the circulation of wealth and credit, on property, on government and taxes, and lastly, on the mistakes of other economic and social theories (De Molinari 1855f, 7-8). By 1863, he had only published a second volume on the circulation and consumption of wealth.
} 
(2004). They tended in the direction of a free market, but regarded laissez-faire more as an orientating principle than anything else. According to this opinion laissez-faire was mainly propagated by "vulgarizers" such as Richard Cobden of the Anti-Corn Law League and James Wilson of The Economist. In France, Jean-Baptiste Say and his school of economists were consistent defenders of a harmonious economic order in which they felt the state should refrain from intervening. They reasoned that completely free competition would lead to growth in production, productivity, and employment (Rothbard 1995, 281).

This position was more in line with the French intellectual tradition going back to the physiocrats. Say accepted the three basic functions of the state - defense, justice, and some public works - from Smith's Wealth of Nations, but did not permit as many exceptions. He attached great importance to education as a means of conditioning citizen behavior (Forget 2001). In the work of Charles Dunoyer and Frédéric Bastiat, the functions of the state were reduced to ensuring security and defense (Sherman 1974). There were few exceptions to laissez-faire in this train of thought. It is important to note that the victory of the Anti-Corn Law League and the depiction of these ideas as Manchester economics by politicians like Benjamin Disraeli led British economists further away from laissez-faire, while in France and Belgium the 1848 Revolution and protectionism led economists in the opposite direction of even more laissez-faire.

The far-reaching opinions of de Molinari about the most efficient way of producing security were, according to Rothbard, the logical end result of the French classical tradition. In Les Soirées de la Rue Saint-Lazare and De la Production de la Sécurité, de Molinari defiantly asked the question why economists like Dunoyer did not go one step further and leave the production of security to the market. If free labor and trade were in the interests of the consumer, then the production of security should also be subjected to the law of free competition. De Molinari stated that natural laws must hold everywhere and at all times, and therefore no exception could be permitted for the production of security (De Molinari 1849a, 280). State monopoly in the production of security entailed a price for the consumer above market value: "The monopoly of government is not more valuable than any other monopoly. One does not govern better, and one certainly does not govern cheaper, when one has no competition to fear... The production of security inevitably becomes expensive and of lower quality when it is organized as a monopoly" (De Molinari 1849b, 308). ${ }^{7}$

De Molinari was not eager for anarchy and lawlessness. In his opinion, the market would provide for a flawless working of society. He used the concept of free competition to explain how society itself could organize defense (Hart 1981a, 263-269). On the one hand, all members of society demanded security. Because not everyone had enough time or the means to provide for their own security, they were prepared to pay for it.

\footnotetext{
7 “Le monopole du gouvernement ne vaut pas mieux qu'un autre. On ne gouverne pas bien, et surtout on ne gouverne pas à bon marché, lorsqu'on n'a aucune concurrence à redouter ... La production de la sécurité devient inévitablement coûteuse et mauvaise lorsqu'elle est organisée en monopole."
} 
On the other hand, some people had natural abilities that made them ideal to become judges, officers, or soldiers. In this situation, the market would provide for security through the formation of property assurance companies that would provide for safety and compensate for any damage. Above all, safety and security would be cheaper and of higher quality because of the competition between the different assurance companies. Consumers would compare the different producers of security. They would have to pay a premium according to their material circumstances and submit to certain rules (De Molinari 1849b, 328-331).

De Molinari's ideas on the role of the state were connected with his conception of human society. According to de Molinari economic science studied the natural organization of society. Political economy showed how society was governed by natural, immutable laws comparable to the law of gravity. The point of departure for de Molinari's reasoning were the many needs of man, the satisfaction or non-satisfaction of which gave enjoyment or suffering: "Man incessantly tries to reduce the sum of his pains and to augment the sum of his pleasures" (ibid., 31). ${ }^{8}$ Because isolated individuals were not able to meet all their own needs, they had an instinct to live in a community and establish a division of labor. The produce of labor was then exchanged between the members of the community. De Molinari thought that society was the result of this elementary organization that originated in the division of labor and exchange of produce (De Molinari 1849a, 277-279). The only prerequisite for this natural order to emerge was the security of property against violence or fraud (De Molinari 1849b, 32-33).

De Molinari's economic system remained fairly schematic in 1849 . He complemented his thoughts on the functioning of the economy with a paper on the formation of prices in 1851. The price mechanism, Smithsian in inspiration, but more radical in its wording and in its consequences, was the regulating principle of the economic world: "There exists an economic law of gravitation that irresistibly restores the market price to the level of the cost of production" (De Molinari 1851, 117). ${ }^{9}$ While prices were the result of supply and demand, they gravitated towards the cost of production. The cost of production was made up of wages and interests. As soon as prices went over or under the cost of production, production would go up or down, pushing the prices back to the cost of production. The result was an equilibrium of production and consumption. De Molinari saw the same mechanism working for the prices of labor and capital. Just like any other price, they were determined by supply and demand and gravitated towards their cost of production. De Molinari thought that this system introduced justice into the economy, because it tended to reward every effort in proportion to the effort itself (De Molinari 1849b, 353-357,

\footnotetext{
8 "L'homme s'efforce donc incessamment de réduire la somme de ses peines et d'augmenter celle de ses jouissances."

9 "Il y a une loi de gravitation économique qui ramène irrésistiblement le prix courant au niveau des frais de production."
} 
and idem 1851). De Molinari and the French tradition were basically optimistic about society and evolution. If the economic order was not disturbed, society would live in abundance and justice would reign in the relations between men. ${ }^{10}$ All the social problems in the world were the result of restrictions on the free working of the natural laws of the economy (De Molinari 1849b, 3-4). These thoughts on the functioning of the economy were the foundation on which all de Molinari's subsequent writings were based. In his last publication, Ultima Verba (1911), he still vigorously defended them.

De Molinari's understanding of the economic world was close to that of most of the French liberal economists. As a science, political economy took on a fixed appearance: the essential principles of the working of the economy were judged to have already been discovered. It was presented as a well-advanced science, not as a science in the making. All its viewpoints were deduced from a small number of axioms about human nature (Breton 1998, 415; Winch 1971, 54). However, although they had read Ricardo, French economists did not indulge in Ricardian-style formalizations. Michel Lutfalla and Yves Breton divided French economists into three schools based on their position on the social question: the ultra-liberals, the moderate liberals, and the heterodox liberals (Breton and Lutfalla 1991, 2-6). The ultra-liberals had an absolute belief in the free workings of the market. Someone like Charles Dunoyer placed great emphasis on the moral origins of the social question: the misery of the working class was a result of their immorality (alcoholism and improvidence). De Molinari was mentioned by Lutfalla and Breton as one of the most intransigent representatives of the ultra-liberal group together with Frédéric Passy and Yves Guyot. There was much affinity between de Molinari and Dunoyer, who had already spoken of the production of security twenty years before de Molinari. Dunoyer's theory was a historical vision in which society evolved in a more liberal direction (Liggio 1977; Allix 1911). However, de Molinari did not share Dunoyer's moralizing discourse on the working classes. The dire fate of the laborers, according to de Molinari, was the result of infringements of economic freedom by socialists and protectionists (De Molinari 1849b, 284). De Molinari was close to a conception of harmony of interests as a spontaneous result of the working of the economy as found in the work of Frédéric Bastiat. Karl Marx therefore called de Molinari the "kind-hearted vulgar free-trade economist de Molinari" (Marx and Engels 1972, 798n). ${ }^{11}$

\footnotetext{
${ }^{10}$ However, de Molinari did concede that the result would not be paradise on earth. But society and its members would find themselves in the best possible situation, given the advancement of the arts and the sciences (De Molinari 1849b, 40-40).

11 "Sanfte, freihändlerische Vulgärökonom Molinari." Marx used the term "vulgar" to indicate the liberal economic tradition after Ricardo. De Molinari remarkably united a laissez-faire stance with some progressive social ideas. He was in favor of obligatory instruction for children because he feared that otherwise parents would exploit them. De Molinari also opposed the inferior legal situation of the laboring classes (Chlepner 1972, 59-61).
} 


\section{The Plea in L'Économiste Belge for a Minimal State}

After his return to Belgium at the beginning of the 1850s, because of Napoleon III's limitations on the economists' freedom, de Molinari was absorbed by his teaching activities. Starting from 1855 he became a central figure in the attempt of Belgian economists to popularize political economy and change the direction of economic policy to a more liberal one. De Molinari started to publish the biweekly journal L'Économiste Belge, Journal des Réformes Économiques et Administratives in 1855. It constantly criticized government intervention in the economy and contained the reports of the meetings of the Sociéte Belge d'Économie Politique. In order to characterize L'Économiste Belge, I will compare it to similar French and British publications.

It is important to stress the difference between the British and the continental situation. There was no professional academic journal for political economy in Great Britain until the end of the nineteenth century. During the first half of that century, economics developed in large part through discussions of the Corn Laws, the Poor Laws, the machinery question, etc. in literary reviews like the Edinburgh Review and the Westminster Review (Berg 1982, 41-42; Kadish 1996, xi-liii; Fetter 1965, 424-425; and Coats 1996, 63-64). In France and Belgium, there was some attention given to political economy in certain general or literary reviews. However, most articles on political economy appeared in the specialized press. In France and Belgium, the monthly Paris-based Journal des Économistes, with Revue de la Science Économique as subtitle during many years, functioned as a specialized scholarly review avant-la-lettre. It had a reading committee that acted as a gatekeeper. It contained articles that were devoted to theoretical issues and others that concerned the economic questions of the day. Very soon, it included reviews of new economic publications.

L'Économiste Belge did not resemble the French Journal des Économistes. It was closer to James Wilson's The Economist, ${ }^{12}$ published weekly since 1843 to promote free trade, and Le Libre Échange. This weekly was launched by Bastiat in 1846 with the same goal of trade liberalization (Gordon 1955; Tyrrell 2006, 107-113). The difference between this type of review and the Journal des Economistes was made by the Journal itself: "The movement for customs reform now has its own weekly, Le Libre Échange, for which it shall be permitted to leave aside the ordinary detachment of scientific inquiry" (Journal des Économistes, quoted in Le Van-Lemesle 2004, 114). ${ }^{13}$ Le Libre Échange had the task

\footnotetext{
${ }^{12}$ In the introduction to the Soirées de la Rue Saint-Lazare de Molinari named James Wilson as an intellectual influence (De Molinari 1849b, 4). He cited this name alongside those of McCulloch, Senior, Dunoyer, Chevalier, Bastiat, and Garnier. It is remarkable that de Molinari did not make a distinction between Wilson's economic journalism and the work of somebody like McCulloch. This actually contributes to the point I will make in the second part of this paper. Authors who are considered popularizers by today's standards were seen by some as proper scientists in their own time.

13 "La réforme douanière a maintenant un hebdomadaire spécial, Le Libre Échange auquel il sera permis de sortir du calme scientifique."
} 
of introducing old truths into political practice, while the Journal was responsible for producing new truths. Like The Economist and Le Libre Échange, L'Économiste Belge's aim was to promote the ideas of political economy to non-specialist readers and to achieve policy change. It was directed at the politically active segment of the public (some two percent of the total Belgian population had voting rights). Various authors believe it was widely read in circles interested in economic, political, and policy questions (Chlepner 1972, 57; Wils 1963, 70-83). It is significant to note that the library of the Belgian Parliament had a subscription to L'Économiste Belge.

Hart believed that de Molinari's contribution to L'Économiste Belge "in no way compromised his anti-statist indictment of government intervention" (Hart 1981a, 277). This is not a correct assessment of de Molinari's ideas in L'Économiste Belge. In his popularization, de Molinari did not propagate the idea of private provision of security and competition between producers of security. On the contrary, he defended the position that government had a (limited) natural function: the defense of life and goods against foreign and internal dangers.

When engaging in popularization de Molinari changed his own line of thinking to arrive at the basic French approach to laissez-faire. ${ }^{14}$ In the first issue, de Molinari made the journal's intentions very clear. L'Économiste Belge was established to propagate the "system of a cheap government." 15 The government should retreat from every activity that remained outside its natural function. Moreover, the government had to improve the services that were within its natural domain (De Molinari 1855b). Interestingly, at this point de Molinari himself differentiated between his scientific and popular work. The mission of L'Économist Belge was to popularize the principles of a low-cost government. It was therefore in a different category than his 1849 work or the recently published first part of the Cours d'Économie Politique. In his journal de Molinari used different arguments and made no references to "natural laws" of the economy. The starting point of the program of L'Économiste Belge was an analysis of the political system. Government was manned by politicians invested with power, which did not necessarily have a good influence. Politicians tried to further their own interests and those of the people around them. The fact that the voting system only allowed payers of high taxes to vote would, according to de Molinari, lead to a policy that did not reflect the general interest. On the contrary, it led to an interventionist policy in matters of agriculture, trade, manufacturing, infrastructure, education, religion, public assistance, the arts, etc.

It seems as if de Molinari was using L'Économiste Belge as the equivalent of a laboratory in the natural sciences. He was applying the theoretical arguments of political

\footnotetext{
${ }^{14}$ It must be mentioned that a few important economists in the liberal tradition, such as Michel Chevalier and Louis Wolowski, were less critical of government intervention. For these moderate and "heterodox" economists, see Breton and Lutfalla 1991, chaps. 3 and 4.

15 “Nous sommes, nous, pour le système du gouvernement à bon marché, et c'est en vue de propager ce système, que nous fondons 'Économiste Belge."
} 
economy to events in the real world. By using real examples and applying the same economic logic over and over again, he reiterated that government intervention was always advantageous to a particular group, while society as a whole had to pay for it. Then society had to make a choice: either government could do a great deal of things, and the public would have to accept high taxes, or the government could restrict itself to the protection of life and goods. De Molinari seemed to have taken Dunoyer's advice to heart. The latter had stated in 1856 that de Molinari lacked practical experience in economics (Dunoyer 1856, 437-438). De Molinari was practicing his arguments in L'Économiste Belge. Thus, he used Adam Smith's argument on the division of labor to discredit government intervention. The basic idea of specialization meant that the government had to focus on security. De Molinari observed that the Belgian government did many other things, from building railways to drainage projects. L'Economiste Belge argued that the government could not accomplish all these activities with the same standards of quality. As a consequence, the production of security suffered from a lack of specialization. Statistics of criminal cases that remained unsolved were used as proof of this argument. Moreover, all activities of the state would be more expensive (De Molinari 1855c).

De Molinari was also trying to make clear that only the ideas of the economists were real science. L'Économiste Belge became involved in discussions with other Belgian journals like Le Précurseur d'Anvers. This much-read publication, based in the port of Antwerp, defended trade interests. As such, it was not unsympathetic to political economy and free trade. However, it fell from de Molinari's grace when it argued that government could take action if private people did not undertake certain activities such as infrastructure, education, and finance. At this point, de Molinari used his viewpoint from 1849: if no clear limits could be set for what constituted justified government intervention, society would eventually drift away into communism. ${ }^{16}$ In the end, every intervention could be legitimized by referring to some special circumstance. If certain infrastructure work was necessary, it would be profitable enough for someone to undertake it (De Molinari 1855e). By reacting to the Antwerp journal, de Molinari clearly placed L'Économiste Belge on the pedestal of absolutely true science. This was a traditional technique he also used in his different dialogues between an economist, a protectionist (or conservative), and a ringleader (or socialist). ${ }^{17}$ Another technique used to gain authority was the certainty with which he put forward his positions in L'Économiste Belge, which contrasted with the more philosophical tone of De la Production.

De Molinari also drew arguments from Jean-Baptiste Say and further developed them. Say had mentioned that governments had too much money at their disposal and

\footnotetext{
${ }^{16}$ Of course, in de Molinari's mind communism was a system where government regulated economic life entirely.

${ }^{17}$ De Molinari used this technique in his Soirées and in his dialogues on the commerce of wheat (De Molinari $1854 b$ and 1855a).
} 
therefore were not interested in the success of their enterprises. They could afford to sell produce below cost because the loss did not have to be paid by the person carrying out the task (Say [1803] 1861, 214). This argument also appeared in the second revised edition of Bastiat's Harmonies Économiques. In the chapter on private and public services, he wrote that public servants had no motivation to perform better (Bastiat 1851). De Molinari applied this argument in particular to the construction of infrastructure by the government. The low motivation of public servants would lead to much more expensive roads and canals (De Molinari 1855d).

De Molinari never explained why he receded from his extreme position of the private provision of security in L'Économiste Belge. Two hypotheses are possible. The first is that de Molinari retreated from his original position because of its rejection by the members of the Paris Société d'Économie Politique. Important figures like Bastiat and Dunoyer, who de Molinari admired, thought a supreme authority was needed to guarantee the underlying security for the market to work ("Chronique" 1849, 315316). He may have been forced to reconsider his position in order to regain entrance to the group of French economists. A second hypothesis is connected to the public and the aim of L'Économiste Belge. If de Molinari wanted to convince people close to the decision-making process such as entrepreneurs, politicians, and government officials, his extreme position on the private provision of security would not have been helpful since even economists who were intellectually close to him found this unacceptable.

\section{The Relationship between Science and Popularization in the Cours d'Économie Politique}

De Molinari returned to scientific work in 1863, when he worked on the second part of his Cours d'Économie Politique. In the introduction he wrote that he had been "engaged in activities that left me with too little leisure to be able to give purely scientific research and speculations the attention they deserve" (De Molinari 1863, I, viii). ${ }^{18}$ From this way of presenting his work, it follows yet again that de Molinari himself differentiated between his popular work in L'Économiste Belge and his scientific research in the Cours. This would appear to confirm the two-step model. However, the return to his scientific activities was not without any influence from his popular work.

The influence of L'Économiste Belge in the Cours was apparent in different ways. The idea that the production of security was a natural function of government remained present in the Cours: police, courts, and army were attributes of all governments at all times (De Molinari 1863, II, 483 and 531). De Molinari used the arguments he had previously elaborated in L'Économiste Belge. He more or less systemized them

\footnotetext{
18 "Engagé dans des travaux qui me laissent trop peu de loisirs pour me permettre d'apporter aux recherches et aux spéculations purement scientifiques l'attention suivie qu'elles réclament. ..”.
} 
in the Cours according to the following four points, or "sins" as he called them, against the principles of good government management (ibid., II, 521-529). First, he argued that government sinned against the division of labor. It wanted to do too much. Secondly, government sinned against the law of natural limits. Every industry had its optimal dimension for production, as had government. Next, government sinned against the law of competition. In some areas of activity, government created a monopoly (e.g. security, postal services). In others, like education or charity, it allowed private competition, but used different instruments to curtail this competition. Because there was no competition or only limited competition, government had no incentive to improve its services and workings. Moreover, government was not obliged to cover its costs because of the lack of competition. This amounted to the conclusion that government worked anti-economically. The fourth sin of government was against the principle of specialization and freedom of exchange. It provided services to consumers who were subjected to its monopoly. Consumers had no choice but to accept the service, without any opportunity to negotiate its price. Moreover, even if the consumers were not interested in the service, they were still obliged to pay for it. De Molinari judged that the less wealthy citizens would suffer most from this state of affairs, because they were not enfranchised.

To these four points, de Molinari added that most European governments could not achieve budget balance. This meant that a part of the costs of public services was passed on to the next generation. De Molinari condemned this kind of action as immoral, giving the next generation the right to refuse payment of these accumulated debts. Like Say, he went on to call government the ulcer of society. The growing government sucked away vital forces from society in the form of taxes which were used in the interests of the class that controlled government. As regards a solution, de Molinari suggested that government be made more economical. As a first step in this direction, government would have to radically limit its activities to providing security. The second step was to provide for competition between governments. De Molinari granted that for the moment this second step was a chimera. Linking it to his conception of the different phases of the historical development of human society, he hoped that in the future the disappearance of the monopoly of politics would not remain a utopian dream (ibid., II, 529-532 and 534).

Apart from the surprising fact that de Molinari turned laissez-faire economics into an instrument against the ruling class, it is interesting for this study that de Molinari's arguments formulated in L'Économiste Belge were also present in his scientific work. He recast his arguments against government intervention in a more formal and systematic way to fit his treatise on political economy. He held on to the provision of security as a natural function of government. As much as he felt that there was a difference between his journalistic writings and his theoretical work, he returned to L'Économiste Belge in his Cours. In a footnote de Molinari even mentioned some of the articles published in his journal to reinforce his argument (ibid., II 532). The implication is clear: the production of science does not remain isolated from its popularization. The 
popularization itself can become a scientific authority. This is confirmation of the work by Gregory Claeys and William Sockwell that popularization is not a one-way street in political economy. Claeys (1985) asserted that some mid-nineteenth-century economists retreated from the distinction between productive and unproductive labor because socialist critics were using it to argue that the working classes deserved a larger share of the profits. Sockwell argued that the version of classical economics popularized by men like James Mill became mainstream economics after 1820 (Sockwell 1994).

Jutta Schickore criticized, appropriately, Cloître and Shinn's idea that texts can be arranged on a scale from specialist, inter-specialist, pedagogical, to popular ones based on intrinsic differences (Schickore 2001, 414). Cloitre and Shinn suggest, on the basis of an analysis of a corpus of publications related to fluid physics, physical chemistry, and mechanics, that texts can be differentiated in terms of the arguments, the referents, and the images they contain. The most telling conclusion was that "the abundance of phenomenological and protocol references and the dearth of historical and industrial considerations clearly distinguish specialist writings" from popular ones. Moreover, "quantitative argument and the property of restrictiveness sharply differentiate specialist and popular texts" (Cloître and Shinn 1985, 32-35). Cloître and Shinn were interested in knowing if the typology they constructed for macroscopic physics was also useful for other disciplines. In the case of the political economy of de Molinari it seems that reference to history and lack of quantitative argument were typical for De la Production de la Sécurité and the Cours. In the Cours, de Molinari developed a theory about the history of civilization in three stages - community, monopoly, and competition - each with their specific functioning of society and different governmental tasks (De Molinari 1863, II, 484). Both read more like a tract in philosophy and are not quantitative. L'Économiste Belge, on the other hand, makes no reference to history, uses statistics to make its point, and is constantly applying the "laws" of political economy to concrete situations.

Based on the publications of de Molinari, I would name reference to history, abstract reasoning, and absence of statistics as the three criteria for specialist texts in political economy, while popular texts would have the opposite characteristics. Many economists, and not only liberal ones, have elaborated theories about the historical stages of economic development, while the lack of quantification, going further than Ricardo's example in his theory of comparative advantages, was notorious with later mathematical economists. Socialists like Hector Denis, the editor of the leflist La Liberté, who went on to become a professor of political economy at the Free University of Brussels, maintained that history and philosophy were characteristics of economic science (Denis 1868, 2). However, if we were to try to apply the categorization of texts based on the proffered parameters to later twentieth-century economics, it would provoke ridicule. Moreover, they do not even hold inside de Molinari's own corpus of publications. In his observations of the formation of prices, for instance, he did use quantitative materials, while it was clearly intended as a contribution to the discussion between specialists. The Cours did not remain completely abstract when de Molinari 
applied his general laws on very concrete issues like monetary policy and the choice of a standard for weights and measures. Internal elements to differentiate between more-scientific and less-scientific texts do not work for de Molinari's case, and I would argue for political economy on the whole before the rise of mathematical economics later in the century. Moreover, as remarked in literary theory, "stylistic criteria" are also always historically located value judgments (Compagnon 1998, 198). Indeed, the characteristics of economic science change constantly as a consequence of the work, discussions, and actions of economists, as I will show in the next section.

\section{The Shifting Boundary between Scientists and Popularizers}

De Molinari himself made a distinction between his scientific production and his other work. So far, I have accepted this demarcation and looked at the relationship between his science and popularization to find it is not as straightforward as implied by the traditional two-step model of popularization. The next section reviews de Molinari's scientific status. Some considerations have to be given to the possibilities of distinguishing between an economist and a popularizer, in an age when professional economists did not exist. Scott Gordon was quite certain that it was possible to divide past political economists into "three P's": the principals or the great masters who developed economic theory, the precursors or the originators, and the propagators who disseminated the ideas. He regarded Richard Cobden and James Wilson as propagators of economics who distorted the ideas of the classical economists, a version which historians of economic thought subsequently pejoratively dubbed the ideology of laissez-faire (Gordon 1955, 461-462). Thomas Sowell was equally certain when he placed Jane Marcet and Harriet Martineau outside classical economics, based on a self-admitted value judgment (Sowell 1974, 6-7). I do not intend to put Martineau or Wilson on the map as serious scientists, only to elucidate that it is not always that easy to draw the boundary between scientific economics and its popularization. ${ }^{19}$

The difficulty is that these authors distinguish science from popularization based on their own value judgments, using certain criteria of what they think scientific production is. I am not willing to draw a line between the "principals" and popularizers based on internal considerations of quality, nor on a canon that has been handed down, since this canon itself is subject to change. The point is that the demarcation criteria themselves alter as scientists engage in strategic practical action to establish the epistemic authority of real science above non-science. In this view, science has no

\footnotetext{
${ }^{19}$ It should be mentioned that Martineau in fact defined herself as a popularizer: "Great men must have their hewers of wood and drawers of water; and scientific discoveries must be followed by those who will popularize their discoveries. When the woodman thinks it necessary to explain that the forest is not of his planting, I may begin to particularize my obligations to Smith and Malthus, and others of their high order" (quoted in Hunter 1995, 27).
} 
essential qualities. Its contours are rhetorically constructed as scientists are confronted with adversaries and audiences (Gieryn 1983 and idem 1999). The example of de Molinari serves us well to show that someone could slip from one category to the other, from scientist to popularizer, during his lifetime. Depending on different points in time and space, de Molinari was considered either a mere journalist or a revered scholar. I will point out how de Molinari was marginalized by his French colleagues, then moved to Belgium to take up a central position in Belgian political economy and subsequently returned to France to become an authority of French liberal political economy.

Rothbard argues that even though the French classical economists did not accept de Molinari's early views on the production of security, they did not treat him as a pariah, but saw his ideas as the logical culmination of their own laissez-faire views (Rothbard 1995, 454). The reaction of the French economists towards de Molinari, however, was more ambiguous. In 1849, the editor of the Journal des Économistes Joseph Garnier felt obliged to publish a footnote justifying the publication of the article De La Production. He accepted the questions de Molinari was asking about the limits of government intervention as relevant in a time when government action had widened, but felt that the article's conclusions were utopian (De Molinari 1849a, 277).

It became very clear during the discussion of de Molinari's ideas in a session of the Société d'Économie Politique in October 1849 that the French economists did not follow his extreme standpoint. The economists attending the discussion argued that without supreme authority, justice and security could not be sanctioned. Competition was only possible if government guaranteed justice and security. Dunoyer regretted that de Molinari had allowed himself to get carried away by the illusion of logic. He thought that competition between insurance companies would end in violent struggles ("Chronique" 1849, 315-316). According to Rothbard's reading of the discussion, the French economists "engaged in pure assertion without argument" and "failed to deal with de Molinari's thesis" (Rothbard 1995, 455-456). Another hypothesis could be that the economists did not want to deal with de Molinari's ideas. The participants had been notified by Horace Say at the beginning of the session that "a very delicate subject" would be discussed. This could be related to the presence of six members of French Parliament during the meeting, one of whom became minister of state education within weeks of the discussion. ${ }^{20}$ Two representatives attended a meeting of the Société for the first time ("Chronique" 1849, 315). If the economists wanted to gain support among French politicians, it surely was not the right time to give de Molinari's ideas serious consideration. On the other hand, it was impossible for them to attack de Molinari with internal arguments, without asking questions about some of the principles behind their own thoughts.

\footnotetext{
${ }^{20}$ Pierre Henri Sainte-Beuve (1819-1855), Camille Lopez-Dubec (1808-1860), Félix de Parieu (1815-1893), Claude-Marie Raudot (1801-1879), Louis Wolowski (1810-1876), and, of course, Frédéric Bastiat (1801-1850). De Parieu became minister on 31 October 1849 (Breton 2005, 130-131 and 133).
} 
De Molinari was further marginalized in an anonymous review of Les Soirées de la Rue Saint-Lazare, which can be attributed to the liberal economist Charles Coquelin. ${ }^{21}$ Coquelin called de Molinari's opinions eccentric. He reproached de Molinari for presenting his own ideas in Les Soirées as if they were the general opinion of the French school of political economists. He acknowledged that competition was the driving principle of the economic world and would yield the best results, but it was unacceptable for any serious economist to extend this idea to the government. De Molinari's mistake, according to Coquelin, was to ignore the precondition that was needed before competition could engender economic activity and order: the repression of fraud and violence by a superior authority. Without a monopolistic government only the law of the jungle would apply. The idea that competition and free choice would still exist in the case of property assurance companies was false, for the individual would be confronted by a much stronger and armed company ([Coquelin] 1849, 364-372).

De Molinari's difficult position was confirmed in 1852 in a short biographical notice in the Dictionnaire d'Économie Politique. It reproduced fragments of the unfavorable review by Coquelin, most of all the opinion that de Molinari's position was eccentric (Coquelin and Guillaumin 1852, II 197). In the same Dictionnaire Coquelin wrote a long entry in which he defined the limits of political economy: "Laissez faire, laissez passer, always has to be accepted in its general expression by anyone who admits that there is such a thing as an economic science" (Coquelin 1852, 656). ${ }^{22}$ One of the main purposes of this definition was to define political economy in such a way that utopian socialist projects would not be allowed as science, but it also placed de Molinari's opinion on the role of government outside science. The idea of laissez-faire implied the existence of an economic order ruled by natural laws. If this order was not acknowledged, as socialists did not, then science had no laws to study. Therefore, no such thing as a socialist science of the economy could exist. Coquelin continued that if the economic order was accepted as a fact, government should not disturb it. However, the primitive and essential function of government was to maintain justice and security. Coquelin added to this function, following Smith, some important works that could not be left to individuals (ibid., 656-657 and 664). This conception of political economy put socialists as well as de Molinari outside its borders.

The reactions to de Molinari's view of the state have to be related to the more general struggle that French liberal political economists were having with socialist ideas. Socialism laid claim to scientific status and was relatively successful in reaching the elites during the 1830s and 1840s. Coquelin wrote that "it is not uncommon these days to hear men of some value, albeit well educated on other points, loudly

\footnotetext{
${ }^{21}$ Fragments of this review were republished some years later in the Dictionnaire d'Économie Politique (Coquelin and Guillaumin 1852, II, 197). They were signed there by Coquelin. De Molinari and Coquelin had actually collaborated before 1849 in efforts to popularize political economy (Hart 1981a, 273-274).

22 "Laissez faire, laissez passer, devra toujours être acceptée dans son expression générale par quiconque admettra qu'il y a une science économique."
} 
proclaim that the economy is left to disorder, to anarchy. This is, in general, the countersign of the so-called socialist schools that we have seen appearing in such large numbers for some years" (ibid., 649). ${ }^{23}$ The influence of socialist ideas during the Paris February Revolution of 1848 and the chaos that ensued were felt very acutely by the liberal political economists. The chair in Political Economy at the Collège de France was temporarily suppressed in April 1848. De Molinari himself lost his teaching position at the Athénée Royal de Paris (De Molinari 1863, I, x). De Molinari made it explicitly clear, like many other French economists at the time, that he considered it his task to defend the science of political economy against socialist thought. While the masters of economic science from Adam Smith to Jean-Baptiste Say had fought the privileges of the Ancien Régime (monopolies and restrictions), de Molinari and his fellow economists had to take on protectionists and socialists alike who maintained that the market was an anarchic place (De Molinari 1863, II, xii-xiii).

However, de Molinari's extreme stance on the production of security was not conducive to furthering the authority of French classical political economy. What Coquelin held against de Molinari in his 1849 review was that, though his explicit goal was to refute socialist ideas, he seriously undercut this effort by mixing his own controversial viewpoints with economic science ([Coquelin] 1849, 372). The element of socialism loomed even larger in Charles Dunoyer's review of the first part of the Cours d'Économie Politique presented before the French Académie des Sciences Morales et Politiques on 16 February 1856. It was annexed to the second edition of the Cours in 1863 , testifying to the importance de Molinari attached to it. ${ }^{24}$ Dunoyer's central criticism was against de Molinari's theory of distribution of wealth. ${ }^{25}$ Here too, de Molinari saw his price mechanism generating equilibrium in establishing the price of labor and capital. Dunoyer reproved de Molinari for having his theory imply the equality of income. The remuneration of the wage worker converged with that of the entrepreneur. Dunoyer remarked that this demonstration was not the best way to answer socialist critiques. He retorted that inequality was a necessity, because it was an incentive to work harder, but was also natural. The differences in income were a result of differences in aptitudes (Dunoyer 1856, 434-436). Dunoyer's conclusion was that de Molinari, in the near future, would count "as one of the best teachers of economic

\footnotetext{
23 “Il n'est pas rare aujourd'hui d'entendre des hommes de quelque valeur, assez instruits d'ailleurs sur d'autres points, proclamer hautement que l'industrie est livrée au désordre, à l'anarchie. Tel est, en général, le mot d'ordre de ces écoles dites socialistes que nous avons vues surgir en si grand nombre depuis plusieurs années."

24 There was a favorable review of the Cours in 1855 by Horace Say in the Journal des Économistes. However it was Dunoyer's reaction in particular that made a profound impression on de Molinari. Dunoyer was an important figure in the French liberal school and a major source of inspiration for de Molinari. In 1863, de Molinari confessed that following the negative review of the first part of the Cours, he was reluctant to write the second part. He only did so because he felt indebted to those who had bought the first volume (De Molinari 1863, I, viii).

${ }^{25}$ Furthermore, Dunoyer attacked de Molinari for structuring his material badly, mixing his own specific ideas with general economic laws and copying the mistakes of earlier writers. The conservative Dunoyer also expressed shock at some of the examples that de Molinari used, such as the "industry of courtesans."
} 
science" (ibid., 438). ${ }^{26}$ The implication was clear: Dunoyer placed de Molinari in the category of popularizers (teachers and journalists) and not in the category of knowledge producers (scientists).

It is possible that the reaction of the French economists played a part in de Molinari's voluntary exile to Brussels after 1851. While de Molinari remained a marginal theoretical figure in French political economy, he was at center stage in the circle of Belgian economists. This supports the view that science is a relative concept, dependent on concrete situations in time and space, and not an absolute one. De Molinari was one of the most active members of the Belgian Political Economy Society in the middle of the 1850s. However, he did not initially become part of the Society's board because he feared that his radicalism would keep some people away. He did become a member of the board a few years later (Erreygers 2001, 96). The Cours d'Économie Politique was well received by economists in Belgium, where Charles Le Hardy de Beaulieu was its most prominent commentator. ${ }^{27}$ In 1855 he wrote that the Cours was one of the best textbooks on political economy (Le Hardy 1855, 206). De Molinari's handling of the theme of rent, among other things, sufficed "to assure M. G. de Molinari of a high rank amongst the masters of the science" (Le Hardy 1861a, 348). ${ }^{28}$ On the whole he evaluated the Cours as a new and important step in the development of economic science (Le Hardy 1863, 356). The most plausible reason why de Molinari was held in higher regard among the Belgian circles of economists than in France was that their activities for change in economic policy needed figures who could provide their struggle some scientific authority. De Molinari's French connection and his positions as lecturer gave them just that.

The post of editor-in-chief of L'Économiste Belge provided de Molinari with the means to gain more scientific authority by actively defending his version of true science. His definition of true economists was that they generally agreed that labor and trade should be free and that government should refrain from any intervention, except for providing security. Economists who made numerous exceptions to the principle of free competition were not pure economists (De Molinari 1849a, 279-280). De Molinari put himself explicitly on the side of science when defending the position that government should not undertake any activities but security. In hammering out his position as scientific truth, de Molinari asserted the authority of French liberal economics over other positions that extended the function of government.

\footnotetext{
26 "Je ne doute pas ... que, dans un avenir prochain, il ne compte au nombre des meilleurs instituteurs de la science économique."

${ }^{27}$ Charles Le Hardy de Beaulieu (1816-1871) was an engineer who taught a course in political economy at the École Spéciale de Commerce, d'Industrie et des Mines in Mons. He authored a Traité Élémentaire d'Économie Politique in 1861 and several papers in the Journal des Économistes. He is chiefly remembered for his contributions to the public debate in Belgium as well as the translation into French of a German textbook by Otto Hübner for use in schools and public libraries. Le Hardy's biographer in the dictionary Biographie Nationale crudely described him as a gifted vulgarizer (Marchant 1890-1891).

28 “... suffirait pour assurer à M. G. de Molinari un rang élevé parmi les maitres de la science ...”.
} 
Boundary-work is explicitly present in the before-mentioned discussion between L'Économiste Belge and Le Précurseur d'Anvers. De Molinari further policed political economy in Belgium by reacting in reviews against, for instance, the Traité Élémentaire d'Économie Politique (1854) by Auguste Royer-De Behr. He asserted that an overview of political economy was far beyond the powers of the newcomer Royer-De Behr (De Molinari 1854a, 135-136).

It should be noted that the position of de Molinari and of political economy on the whole as a science was not universally recognized in Belgium. While most trade barriers had been eased by the end of the 1850s, most Belgian politicians did not accept the priority of economic science over politics. According to the Belgian Conservative politician Barthélemy Dumortier in 1857, Jean-Baptiste Say and his school were completely outdated (Chambre des Représentants 1857,638 ). On the socialist side, the liberal economists had absolutely no legitimacy. In 1868 Hector Denis did concede to de Molinari that the market was not completely anarchic. Nevertheless, government intervention was justified because the equilibrium in the economy always remained far away. Denis considered the liberal political economy of publicists like Bastiat and de Molinari to be a religion and not a science (Denis 1868, 2).

De Molinari returned to Paris in 1867, this time to become a respected member of the French classical economists and even to be seen as the ultimate exponent of French laissez-faire economics. Two elements contributed to this. First, de Molinari had gained authority because of his activities in Belgium. During his years in Belgium he regularly sent reports to the editor of the Journal des Économistes on the development of the Belgian free trade campaign. He also published on the economic situation in Belgium (De Molinari 1856a, 1856b, and 1859). Thus he became a spokesperson for the Belgian community of free trade economists and a specialist on the Belgian economic situation. Second, de Molinari reworked parts of his Cours d'Économie Politique for the second edition in 1863, taking into account Dunoyer's criticism. de Molinari now granted that differences in income were the result of unequal capacities. Moreover he conceded that competition between governments, although theoretically the best option, was something that could only be achieved in a far-off future. Both changes were remarked in a long review of the Cours by Ambroise Clement in the Journal des Économistes, that gave the new edition a moderately positive evaluation (Clément 1864, 213-227).

From 1881, de Molinari was in charge of the Journal des Économistes (Laurent and Marco 1996, 90). In an obituary for de Molinari in 1912, Yves Guyot, the next director of the Journal, wrote that our protagonist had produced a series of scientific works of the first order in the history of ideas. Guyot put de Molinari plainly within the realm of science (Guyot 1912). Frédéric Passy, colleague-economist and laureate of the Nobel Prize for peace, wrote in 1904 (eight years before de Molinari's death) that de Molinari was the doyen of the liberal economists (Passy 1904, xxviii). De Molinari outlived all other economists who were active in the Société d'Économie Politique and the Journal des Économistes in Paris in the 1840s and 1850s. Thus it happened that he became the symbol of a generation of economists who did not always accept his extreme point of 
view. Moreover, de Molinari became a major influence on the eminent sociologist and economic theorist Vilfredo Pareto (1848-1923), who addressed him as Cher maitre. ${ }^{29}$ In his writings, Pareto referred to de Molinari in favorable terms and cited him on many occasions (Rothbard 1995, 455-459; Mornati 2000).

By this time, however, the French liberal school was starting to be seriously contested inside France and was beginning to lose its international prestige. It was no longer a more or less generally accepted scientific community, and the community itself slowly fell apart because of internal disagreement. When the discipline of political economy finally became institutionalized at the French faculties of law, the newly founded economics chairs were occupied by faculty members with more heterodox views on economics. The new French professors grew increasingly tired of the hegemonic position of the liberal economists around the Journal des Économistes, the Political Economy Society, and the Academy of Moral and Political Sciences. A new episode now approached, in which a younger generation of economists and the representatives of the French liberal school contested each other's scientific authority. De Molinari played an important part in these discussions as the editor-in-chief of the Journal des Économists and as one of the most prominent representatives of the old liberal school. The economics professors based in the law faculties saw the members of the liberal school as amateurs and journalists without any formal training (Breton 1998, 410416). Gradually laissez-faire became a characteristic not of science, as de Molinari had wanted, but of popular science (Cole 1933, 17; Keynes 1972, 277-278, 281).

\section{Conclusion}

In the past decade there has been renewed interest in de Molinari's ideas. Together with Frédéric Bastiat, he has become a somewhat iconic figure for laissez-faire liberals and what is known as the Austrian school of economics. Two recently created think-tanks have even been named after him (L'Institut Économique Molinari and the Molinari Institute). It seems that once more the boundary between science and popularization is changing. In conclusion, I would like to point out the implications of my study for the relationship between science and popularization in the field of political economy.

De Molinari himself distinguished his popular work from his scientific work. He felt that the activity of popularization was something other than scientific work. This seems to point in the direction of the traditional two-step model. However, even though de Molinari himself saw a clear distinction between science and popularization, this was less straightforward than it might seem. The fact that he mentioned McCulloch, Senior, Wilson, Dunoyer, Chevalier, Bastiat and Garnier in the same breath indicates as much. In the field of the history of economic thought, only the first two personalities generally qualify as scientists. Who was considered a scientific economist before economics

\footnotetext{
${ }^{29}$ For instance, in a letter from Pareto to de Molinari, 18 November 1896 (Pareto 1975, 406).
} 
became institutionalized at the university level is a moot point. Much depends on the observer's point of view. The boundary-work done by economists - that is, the contours of science that are rhetorically constructed to deal with adversaries, and the networks forged around ideas - account for who is considered a scientist at any given moment. However, even the advent of institutionalized economics at the end of the nineteenth century does not solve the problem. As Augello and Guidi (2001) point out, different forms of institutionalization already existed in the middle of the nineteenth century. Although de Molinari was an active member of different economics societies and taught at two technical institutes, his status as a scientist was not secure. Whether de Molinari was considered a scientist or a mere journalist depended on his acceptance as such by the relevant groups over time. As shown in this paper, his status changed more than once during his lifetime. He shifted from scientist to popularizer and back.

Moreover, the two-step model does not work when analyzing the internal relationship between De la Production de la Sécurité, L'Économiste Belge, and the Cours d'Économie Politique. It becomes apparent that de Molinari's science production was not isolated from his popularization. De Molinari made reference to and used arguments from L'Économiste Belge in his scientific work. His definition of true science did not exclude his own popularization. The idea that texts can be arranged on a scale from scientific to popular based on the internal characteristics of science does not fit the evidence. Indeed, the characteristics of "scientific" political economy change constantly as a consequence of the work, discussions, and actions of economists.

It is fruitful to see the popularization of economics around 1850 as a strategy to gain scientific authority over socialism and protectionism. In that sense, popularization is part and parcel of the scientists ordinary activity. The scientific status of economics depended on the possibility of implementing free trade and laissez-faire in "real" countries and on discrediting socialist utopias. Only by bringing reality into agreement with their ideas on economic freedom could classical economists demonstrate they were right. Until that moment, political economy remained theory. This is why the repeal of the Corn Laws in 1846 was such a significant event in the history of economics. The experiment with free trade in Great Britain after that date added weight to the idea that economic freedom was productive of prosperity. Belgium, which made the move to free trade in the 1850 s, was also cited as an example (Orts s.d.). Popularization was thus central to the endeavor to affirm the scientific status of political economy on the continent.

\section{Acknowledgements}

This paper was first presented at the tenth annual conference of the European Society for the History of Economic Thought in Porto, Portugal, 28-30 April 2006. I am grateful to Charles McCann, Guido Erreygers, Bruno Boute, and two anonymous referees for their comments on earlier versions of this paper. 


\section{References}

Allix, Edgard. 1911. "La Déformation de l'Économie Politique Libérale Après J.-B. Say: Charles Dunoyer." Revue d'Histoire des Doctrines Économiques et Sociales 4:115-147.

Association Belge Pour la Liberté Commerciale. 1846. Première Séance Publique de l'Association Belge Pour la Liberté Commerciale, Tenue en la Salle de la Philharmonie, 11 octobre 1846. Brussels: Imprimerie du Journal la Constitution.

Augello, Massimo M. and Marco E. L. Guidi. 2001. "Nineteenth-Century Economic Societies in a Comparative Approach. The Emergence of Professional Economists." In The Spread of Political Economy and the Professionalisation of Economists, edited by Massimo M. Augello and Marco E. L. Guidi, 1-31. London/New York: Routledge.

Bastiat, Frédéric. 1851. Harmonies Économiques, 2nd revised ed. Paris: Guillaumin.

Berg, Maxine. 1982. The Machinery Question and the Making of Political Economy 1815-1848. Cambridge: Cambridge University Press.

Breton, Yves and Michel Lutfalla, eds. 1991. L'Économie Politique en France au XIXe siècle. Paris: Economica.

Breton, Yves. 1998. "French Economists and Marginalism (1871-1918)." In Studies in the History of French Political Economy. From Bodin to Walras, edited by Gilbert Faccarello, 404-455. London/New York: Routledge.

Breton, Yves. 2005. "French Economists in Parliament from the Second Republic to the Outbreak of the Great Crisis (1848-1929)." In Economists in Parliament in the Liberal Age (1848-1920), edited by Massimo M. Augello and Marco E. L. Guidi, 129-162. Aldershot: Ashgate.

Catalogue des Livres Anciens et Modernes et des Estampes Provenant des Collections de Feu MM. G. de Molinari, et Fernand Popelin, et de M. E. De Vigne. 1913. Brussels: Deman.

Chambre des Représentants. (2 February) 1857. Annales Parlementaires du Chambre, 638. Brussels: Chambre des Représentants.

Chlepner, Ben Serge. 1972. Cent Ans d'Histoire Sociale en Belgique, fourth edition. Brussels: Éditions de l'Université de Bruxelles.

“Chronique.” 1849. Journal des Économistes 8(24):315-316.

Claeys, Gregory. 1985. "The Reaction to Political Radicalism and the Popularisation of Political Economy in Early Nineteenth-Century Britain." In Expository Science: Forms and Functions of Popularisation, edited by Terry Shinn and Richard Whitley, 119-136. Dordrecht/Boston/Lancaster: Reidel.

Clément, Ambroise. 1864. "Cours d'Économie Politique, par M. G. de Molinari." Journal des Économistes 23(second series nr. 122):213-227.

Cloître, Michel and Terry Shinn. 1985. "Expository Practice. Social, Cognitive and Epistemological Linkage." In Expository Science: Forms and Functions of Popularisation, edited by Terry Shinn and Richard Whitley, 31-60. Dordrecht/Boston/Lancaster: Reidel.

Coats, Alfred William. 1996. "British Nineteenth Century Economic Periodicals." History of Economic Ideas 4(3):63-75.

Cole, George Douglas Howard. 1933. "Laissez Faire.” In Encyclopaedia of the Social Sciences, edited by Edwin R. A. Seligman and Alvin Johnson, vol. 9, 15-20. New York: Macmillan.

Compagnon, Antoine. 1998. Le Démon de la Théorie. Littérature et Sens Commun. Paris: Seuil.

[Coquelin, Charles]. 1849. "Les Soirées de la Rue Saint-Lazare. Entretiens Sur les Lois Économiques et Défense de la Propriété, par M. G. de Molinari." Journal des Économistes 8(24):364-372.

Coquelin, Charles. 1852. "Économie Politique." In Dictionnaire de l'Économie Politique Contenant l'Exposition des Principes de la Science, edited by Charles Coquelin and Gilbert-Urbain Guillaumin, vol. I, 643-670. Paris: Guillaumin.

Coquelin, Charles and Gilbert-Urbain Guillaumin. 1852. Dictionnaire de l'Économie Politique Contenant l'Exposition des Principes de la Science, 2 vols. Paris: Guillaumin.

Corr-Van der Maeren, Michel and Auguste Couvreur. 1874. "Le Mouvement Économique en Matière Commerciale." In Patria Belgica. Encyclopédie Nationale. Deuxième Partie. Belgique Politique et Sociale, edited by Eugène Van Bemmel, 784-804. Brussels: Bruylant. 
De Molinari, Gustave. 1849a. "De la Production de la Sécurité.” Journal des Économistes 8(22):277-290.

De Molinari, Gustave. 1849b. Les Soirées de la Rue Saint-Lazare; Entretiens Sur les Lois Économiques et Défense de la Propriété. Paris: Guillaumin.

De Molinari, Gustave. 1851. “Observations Sur la Formation des Prix.” Journal des Économistes 10(29):111128.

De Molinari, Gustave. 1854a. "Traité Élémentaire d’Économie Politique par Royer de Behr.” Journal des Économistes 13(second series 4):135-136.

De Molinari, Gustave. 1854b. "Le Commerce des Grains. Dialogue Entre un Émeutier, un Économiste et un Prohibitioniste." Journal des Économistes 13(second series 4):186-204.

De Molinari, Gustave. 1855a. "Le Commerce des Grains. Dialogue Entre un Émeutier, un Prohibitioniste et un Économiste." Journal des Économistes 14(second series 6):52-64.

[De Molinari, Gustave]. 1855b. "[Editorial]." L'Économiste Belge 1(1):1-3.

[De Molinari, Gustave]. 1855c. "L'Administration de la Justice." L'Économiste Belge 1(11):1-3.

[De Molinari, Gustave]. 1855d. "Les Voies de Communication - Deux Canaux qui Coûtent Trop Cher." L'Économiste Belge 1(14):3-4.

[De Molinari, Gustave]. 1855e. "L'Intervention Gouvernementale - Réponse au Précurseur." L'Économiste Belge 1(16):6.

De Molinari, Gustave. 1855f. Cours d'Économie Politique. Tome I. La Production et la Distribution des Richesses. 1st edition. Brussels: Decq.

De Molinari, Gustave. 1856a. "Situation Économique de la Belgique." Journal des Économistes 15(second series 10):331-354.

De Molinari, Gustave. 1856b. "L'Agitation Pour les Réformes Économiques en Belgique." Journal des Économistes 15(second series 11):193-209.

De Molinari, Gustave. 1859. "Correspondance. A Monsieur le Rédacteur en Chef du Journal des Économistes." Journal des Économistes 18(second series 24):421-430.

De Molinari, Gustave. 1863. Cours d'Économie Politique. Tome I. La Production et la Distribution des Richesses, 2nd edition. Brussels/Leipzig: Lacroix-Verboeckhoven.

De Molinari, Gustave. 1863. Cours d'Économie Politique. Tome II. La Circulation et la Consommation des Richesses. Brussels/Leipzig: Lacroix-Verboeckhoven.

[De Molinari, Gustave]. 1868. “A Nos Abonnés.” L'Économiste Belge 14(26):301-302.

De Molinari, Gustave. 1911. Ultima Verba: Mon Dernier Ouvrage. Paris: Giard et Brière.

Denis, Hector. 1868. "Nécessité d'un Droit Économique." La Liberté 26 April 1868 44:2.

Dunoyer, Charles. 1856. "Cours d'Économie Politique, par M. G. de Molinari." Journal des Économistes 15(second series 9):429-438.

Erreygers, Guido. 2001. "Economic Associations in Belgium." In The Spread of Political Economy and the Professionalisation of Economists. Economic Societies in Europe, America and Japan in the Nineteenth Century, edited by Massimo M. Augello and Marco E. L. Guidi, 91-108. London/New York: Routledge.

Erreygers, Guido and Bert Mosselmans. 2005. "Economists in the Belgian Parliament (1831-1918)." In Economists in Parliament in the Liberal Age (1848-1920), edited by Massimo M. Augello and Marco E. L. Guidi, 49-74. Aldershot: Ashgate.

Fetter, Frank Whitson. 1965. "Economic Controversy in the British Reviews, 1802-1850." Economica 32(128):424-437.

Forget, Evelyn L. 2001. “Jean-Baptiste Say and Spontaneous Order.” History of Political Economy 33(2):193218.

Garnier, Joseph. 1851. Lettre from Garnier to de Brouckère, 6 October 1851. Brussels, Belgian State Archives, Papiers de Brouckère, nr. 42.

Garnier, Joseph. 1869. "L'Économiste Belge Cesse de Paraitre. Services qu'il a Rendus." Journal des Économistes 28(third series 13):180.

Gieryn, Thomas F. 1983. "Boundary-Work and the Demarcation of Science from Non-Science: Strains and Interests in Professional Ideologies of Scientists." American Sociological Review 48(6):781-795. 
Gieryn, Thomas F. 1999. Cultural Boundaries of Science: Credibility on the Line. Chicago/London: University of Chicago Press.

Gordon, Scott. 1955. "The London Economist and the High Tide of Laissez-Faire." Journal of Political Economy 63(6):461-488.

Gregory, Jane. 2003. "The Popularization and Excommunication of Fred Hoyle's "Life-from-space" Theory." Public Understanding of Science 12:25-46.

Guyot, Yves. 1912. “M. G. de Molinari.” Journal des Économistes 71(sixth series 33):177-192.

Hart, David M. 1981a. "Gustave de Molinari and the Anti-Statist Liberal Tradition. Part I." Journal of Libertarian Studies 5(3):263-290.

Hart, David M. 1981b. "Gustave de Molinari and the Anti-Statist Liberal Tradition. Part II." Journal of Libertarian Studies. 5(4):399-434.

Hart, David M. 1982. "Gustave de Molinari and the Anti-Statist Liberal Tradition. Part III." Journal of Libertarian Studies 6(1):83-104.

Hilgartner, Stephen. 1860. "Nécrologie Charles de Brouckère.” Journal des Économistes 18(second series 26):265-267.

Heuschling, Xavier. 1990. “The Dominant View of Popularization: Conceptual Problems, Political Uses." Social Studies of Science 20(3):519-539.

Howe, Anthony. 1997. Free Trade and Liberal England 1846-1946. Oxford: Clarendon Press.

Hunter, Shelagh. 1995. Harriet Martineau. The Poetics of Moralism. Aldershot: Scolar Press.

Kadish, Alon. 1996. The Corn Laws. The Formation of Popular Economics in Britain. London: William Pickering.

Keynes, John Maynard. [1926] 1972. “The End of Laissez-Faire.” In The Collected Writings of John Maynard Keynes. Volume IX Essays in Persuasion, 272-294. London/Basingstoke: Macmillan.

Knight, David. 2006. Public Understanding of Science. A History of Communicating Scientific Ideas. London/New York: Routledge.

Laurent, Evelyne and Luc Marco. 1996. "Le Journal des Économistes ou l'Apologie du Libéralisme (1841-1940)." In Les Revues d'Économie en France. Genèse et Actualité 1751-1994, edited by Luc Marco, 79-120. Paris/Montreal: L'Harmattan.

Le Van-Lemesle, Lucette. 2004. Le Juste ou le Riche. L'Enseignement de l'Économie Politique 1815-1950. Paris: Comité Pour l'Histoire Économique et Financière de la France.

Le Hardy de Beaulieu, Charles. 1855. "Cours d'Économie Politique, Professé au Musée Royal de l'Industrie Belge, par M. G. De Molinari.” Revue Trimestrielle 2(5):204-211.

Le Hardy de Beaulieu, Charles. 1861a. "Questions d'Économie Politique et de Droit Public, par G. de Molinari." Revue Trimestrielle 8(31):347-352.

Le Hardy de Beaulieu, Charles. 1861b. Traité Élémentaire d'Économie Politique. Brussel: Lacroix-Van Meenen.

Le Hardy de Beaulieu, Charles. 1863. "Cours d'Économie Politique, par M. G. de Molinari, Professeur au Musée de l'Industrie, Directeur de L’Économiste Belge, etc. etc. Deuxième Édition, Revue et Augmentée." Revue Trimestrielle 10(40):341-357.

Liggio, Leonard P. 1977. "Charles Dunoyer and French Classical Liberalism.” Journal of Libertarian Studies 1(3):153-178.

Lubelski-Bernard, Nadine. 2001. “de Molinari, Gustave.” In Nouvelle Biographie Nationale 6:135-143. Brussels: Académie Royale des Sciences, des Lettres et des Beaux-Arts de Belgique.

Marchant, Albert. 1890-1891. "Le Hardy de Beaulieu (Jean-Charles-Marie-Joseph)." In Biographie Nationale 11:709-714. Brussels: Bruylant.

Marx, Karl and Friedrich Engels. 1972. Werke, Band 23, Das Kapital. Kritik der Politischen Ökonomie. Erster Band. Buch I. Berlin: Dietz.

Mornati, Fiorenzo. 2000. "Gustave de Molinari et Yves Guyot Nella Formazione del Pensiero Paretiano Fino al 'Cours d'Économie Politique'." In Economia, Sociologia e Politica Nell'Opera di Vilfredo Pareto, edited by Corrado Malandrino and Roberto Marchionatti, 247-271. Firenze: Olschki. 
O'Brien, Denis Patrick. 2004. The Classical Economists Revisited. Princeton and Oxford: Princeton University Press.

Orts, Auguste. [s.d.] Cours d'Économie Politique Professé à l'Université de Bruxelles. Unpublished college notes. Brussels, Belgian State Archives, Papiers Orts, nr. 386.

Pareto, Vilfredo Federico Damaso. 1975. Correspondance, 1890-1923. (Oeuvres complètes vol. 19), edited by Giovanni Busino, Genève: Droz.

Passy, Frédéric. 1904. "Prefatory Letter." In The Society of Tomorrow, by G. De Molinari, xxviii-xxix. New York: Putnam.

Paul, Ellen Frankel. 1979. Moral Revolution and Economic Science: The Demise of Laissez-Faire in NineteenthCentury British Political Economy. Westport, Conn: Greenwood.

Robbins, Lionel Charles. 1952. The Theory of Economic Policy in English Classical Political Economy. London: Macmillan.

Rothbard, Murray Newton. 1995. Classical Economics. An Austrian Perspective on the History of Economic Thought. Volume II. Cheltenham/Northampton, MA: Edward Elgar.

Say, Jean-Baptiste. [1803] 1861. Traité d'Économie Politique, 7th edition. Paris: Guillaumin.

Say, Horace. 1855. "Cours d'Économie Politique Professé au Musée de l'Industrie Belge, par M. G. de Molinari." Journal des Économistes 14(second series 6):146-150.

Sherman, Dennis. 1974. "The Meaning of Economic Liberalism in Mid-Nineteenth-Century France." History of Political Economy 6(2):171-199.

Schickore, Jutta. 2001. “The Task of Explaining Sight: Helmholtz's Writings on Vision as a Test Case for Models of Science Popularization." Science in Context 14(3):397-417.

Sockwell, William D. 1994. Popularizing Classical Economics. Henry Brougham and William Ellis. New York: St. Martin's Press.

Sowell, Thomas. 1974. Classical Economics Reconsidered. Princeton, N.J: Princeton University Press.

Suetens, Max. 1955. Histoire de la Politique Commerciale de la Belgique Depuis 1830 Jusqu'à Nos Jours. Brussels: Librairie Encyclopédique.

Tyrrell, Alex. 2006. "La Ligue Française. The Anti-Corn Law League and the Campaign for Economic Liberalism in France During the Last Days of the July Monarchy." In Rethinking Nineteenth-Century Liberalism. Richard Cobden Bicentenary Essays, edited by Anthony Howe and Simon Morgan, 99-116. Aldershot: Ashgate.

Van Dijck, Maarten. Forthcoming 2008. De Wetenschap van de Wetgever. De Klassieke Politieke Economie en het Belgische Landbouwbeleid, 1830-1884 [The Legislator's Science. Classical Political Economy and Belgian Agricultural Policy, 1830-1884]. Leuven: University Press Leuven.

Viner, Jacob. 1927. “Adam Smith and Laissez Faire.” The Journal of Political Economy 35(2):198-232.

Whitley, Richard. 1985. "Knowledge Producers and Knowledge Acquirers. Popularisation as a Relation Between Scientific Fields and Their Publics." In Expository Science: Forms and Functions of Popularisation, edited by Terry Shinn and Richard Whitley, 3-28. Dordrecht/Boston/Lancaster: Reidel.

Wils, Lode. 1963. Het Ontstaan van de Meetingpartij te Antwerpen en Haar Invloed op de Belgische Politiek [The Creation of the Meetingparty in Antwerp and Its Influence on Belgian Politics]. Antwerp: Nederlandsche Boekhandel.

Winch, Donald. 1971. The Emergence of Economics as a Science: 1750-1870. London: Collins. 